\title{
Health status of elderly persons of Antioquia, Colombia
}

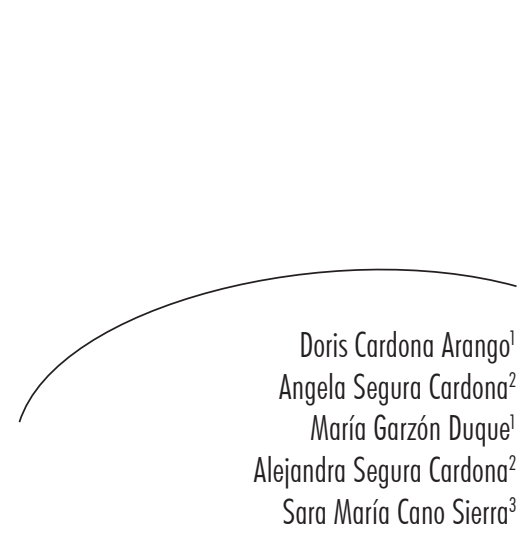

\section{Abstract}

Objective: The health needs of older adults constitute challenges for health monitoring and care, resulting in increased costs. The present study therefore sought to analyze the health status of the elderly to enable targeting and intervention, in the pursuit of healthy aging for all. Method: A quantitative observational cross-sectional study using a primary source was performed in 2012. A total of 4,248 adults aged over 60 years of age residing in the nine regions of Antioquia, Colombia, and the capital city were surveyed. Univariate, bivariate and multivariate analysis was performed of statistical and epidemiological measures, based on confidence intervals and statistical tests under $5 \%$. Results: One in four individuals had a risk of depression, one in three were at risk of anxiety, eight out of ten had cognitive impairment, mainly mild, and the same proportion were at nutritional risk.

Key words. Elderly; Health Status; Elder Abuse; Mental Health. The elderly persons suffered from all types of abuse, notably psychological. Conclusions: Thehealth status ofelderly personsis more affectedbymental than physical healthrisks, indicatingthatpublic policy anda better distribution ofresourcesshould be aimed at seeking animprovement in qualityof life anddignified aging, differentiated byregion.

\footnotetext{
Universidad CES, Grupo de Investigación Observatorio de la Salud Pública. Medellín, Colombia.

2 Universidad CES, Grupo de Investigación Epidemiología y Bioestadística. Medellín, Colombia.

Hospital Municipio de Anorí. Medellín, Colombia.
}

Funding: This research project was carried out through a partnership agreement between the Government of Antioquia - Secretaria Seccional de Salud y Protección Social de Antioquia (Regional Secretary of Health and Social Protection of Antioquia) and Universidad CES-Facultad de Medicina - 2012CF164156. 


\section{INTRODUCTION}

The health situation analyses (HSA) of the Pan American Health Organization (PAHO), ${ }^{1}$ are analytic-synthetic processes involving a range of interpretations which allow the characterization, measurement and explanation of the health-disease profile of a population, including health problems and their determinants, whether arising from health or other sectors, facilitating the identification of needs and priorities in health interventions and appropriate programs, and evaluating their impact on health through the study of the interaction of living conditions and the existing level of health processes of a country or other geographical and political unit.

The sublevels of the HSAs include population groups of different levels of development arising from unequal conditions and quality of life and defined according to specific characteristics ${ }^{1}$. One of these groups is those aged over 60, which is considered a vulnerable population group and a healthcare priority, protected by the Constitution (Article 46) and by the Política Nacional de Envejecimiento y Vejez (the National Policy on Aging and Old Age). ${ }^{2}$

The study of the elderly reveals the process of aging among a population, which will become a major issue in developing countries, where the population is projected to age rapidly in the first half of this century. It is expected that by 2050 the elderly population will grow from $8 \%$ to $19 \%$ of the overall population, while the number of children will fall from $33 \%$ to $22 \%$. This demographic shift poses a major problem in terms of resources; developed countries have aged gradually and face problems related to unemployment and the sustainability of pension systems, while developing countries face the problems of underdevelopment at the same time as those related to population aging. ${ }^{3}$

Of the aspects that accompany population aging, the health situation creates great challenges to societies through demographic and epidemiological transitions that transform the causes of disease and death from communicable to chronic, degenerative and disabling, increasing the costs of care and rehabilitation required by patients ${ }^{4}$. The health needs of the elderly are a cause for concern among the population, as they take up a very large proportion of attention and care, increase costs and uncertainty due to their chronic nature, which often end up depleting the resources of support within social networks, and increasing the frequency of illness, bringing a loss of function, resulting in physical and economic dependence on other family members.

It is not enough, however, to merely add years to life. Adding life to years is also required, creating a greater expectation of health and wellness for a longer period. Improving the quality of life of aging older people, ${ }^{5}$ fosters self-esteem and dignity and the full exercise of all human rights and fundamental freedoms. ${ }^{6}$ The consequences of social changes can also negatively influence the living conditions and health of the elderly, which include social responses to the biological deterioration of aging itself; loss of employment, loss of income and the impairment of social identity. ${ }^{7}$

This indicates that the growth of the elderly population inevitably results in an increase in the physical and mental illnesses related to age, which will increase the costs of health care and place greater demands on family and social resources; mental illnesses, especially depression, are expected to be the major mental health problem facing the world in the future. Mental and behavioral disorders disrupt the quality of life of those affected and their families. ${ }^{4}$

Additionally, biological and social changes mean the elderly are also exposed to other risks that impair their health, such as depression, anxiety, cognitive impairment and malnutrition. These conditions, however, have been little explored among this population, being considered inherent among the elderly, leading to functional and economic dependence on the state, society and 
family, and often leaving such individuals subject to neglect, abuse and violence. ${ }^{2}$ In this way, a cultural paradigm shift is required, from a way of thinking where age is linked to disease, dependency and lack of productivity, to another where the elderly are considered as autonomous, productive and the beneficiaries of development. It was therefore proposed to analyze the health status of the elderly living in the nine regions and in the capital of the Department of Antioquia in the second half of 2012, making possible targeting and intervention to achieve dignified, healthy aging for everyone, based on the specific conditions of their place of residence.

\section{METHOD}

Using a quantitative approach and the empiricalanalytical method, a cross-sectional observational, descriptive study was conducted in the nine regions and capital city of the department of Antioquia, Colombia, in 2012. For purposes of sample design, 10 regions were considered.

The reference population was people aged 60 and older residing in urban areas and population centers in the sub-regions, which according to the population projections of the Departamento Administrativo Nacional de Estadística (National Administrative Department of Statistics) (DANE) was estimated at 671,590 adults aged over 60 years in the year 2012. The Epidat 3.1 program and the Fleiss formula for finite populations was used to calculate the sample size, with a confidence level of $95 \%$, a sampling error of $1.6 \%$, a ratio of good health of $50 \%$ and a design effect (deff) of 1.0. The minimum sample size was calculated at 3790 and expanded by $10 \%$ to correct possible data loss, leaving a final simple size of 4,248 elderly persons.

The representative sample of each subregion was selected by two-stage, systematic and random probability cluster sampling; the final selection probabilities of each elderly individual were calculated to ascertain the expansion factors. A total of 36 municipalities (four per sub-region) plus four districts of the capital city were selected in total. People aged 60 years and older living in municipal districts, population units and selected population centers were surveyed irrespective of ethnicity, religious denomination or physical condition. The elderly residents of nursing homes and those who scored less than 24 points in the Mini Mental State Examination (MMSE) ${ }^{8}$ at the beginning of the survey were excluded. This test assesses the cognitive functioning of an individual, with a score lower than 24 a first sign of alarm for evidence of impairment, and lack of knowledge of the type of denture used the second signal, to determine the awareness of reality of an elderly individual.

The elderly individuals were selected by 12 interviewers. These were university graduates in the areas of social studies or information systems, who were previously trained and standardized for two weeks by the researchers in the study design, implementation of surveys, sampling and fieldwork. Verification of field work and quality assurance of the measuring instrument was carried out with two supervisors. The data collection period was 1.5 months.

The survey was previously calibrated with a pilot study, and consisted of 104 questions including variables related to: demographic characteristics (such as age, gender, marital status, education level, place of residence); cognitive functioning (the Folstein MMSE); level of depression (Short Form Geriatric Depression Scale); level of anxiety (anxiety subscale of the Goldberg Depression and Anxiety Scale (GDAS)); Katz Index; social support (OARS social resources scale); perception of abuse and nutritional status (DETERMINE instrument). All these instruments were taken from the Manual of Indicators for quality of life in old age of the Centro Latinoamericano y Caribeño de Demografía (Latin American and Caribbean Demographic Center).?

Data processing was performed using the EpiInfo software package version $6.04 \mathrm{~d}$ (freeware) and the SPSS 21.0 statistical package (CES University 
license). Univariate, bivariate and multivariate analysis were performed. Univariate is performed with expansion factors and estimation errors are calculated, in addition to measures of absolute and relative frequency; Descriptive summary measures such as mean, median, mode, standard deviation (SD), and interquartile range are also calculated. Bivariate analysis is performed without growth factors, where the demographic variables are related to the scales used, according to the Chi-squared hypothesis test, and epidemiological measures such as crude and adjusted prevalence ratio (PR) are calculated, with a confidence interval of $95 \%$. A statistical significance of $5 \%$ was established for the tests.

Expansion factors are a technique of inferential statistics, which are based on the calculation of expanders or weightings with which it is intended to reconstruct the reference population from which the sample was obtained. These factors were calculated based on the probability of selection of the municipality and population units; the final probability of selection of the elderly individuals, the inverse of which is the basic expansion factor, which equals the number of elderly individuals in the region that are initially represented by each of the respondents. Subsequently, the basic expansion factor was adjusted by the correction factors: coverage, non-response, gender and area of origin. The expanded population was 654,712 elderly persons in the department, and the proportion of good health found was $52.9 \%$.

Finally, the estimation errors, which are the final errors related to the variable of interest used in the calculation of the sample size, were calculated. This error was established as $1.49 \%$ for the departmental estimates of state of health and from $4.30 \%$ to $4.84 \%$ for regional estimates.

This study was approved by the "Comité Institucional de Ética de la Universidad CES" (Institutional Ethics Committee Universidad CES),
Medellín-Colombia (registration $n^{\circ} 53 / 2012$ ) and written informed consent was obtained from the elderly individuals, upon completion of the survey, based on Resolution 8430 of 1993 the Ministry of Health, which regulates research involving human beings. Furthermore, according to the same standard, this research was classified as having minimal risk for the elderly.

\section{RESULTS}

\section{Demographic characteristics}

Among the older adults from the Department of Antioquia there was a higher proportion of women $(72.8 \%)$, with 2.68 women for every man in this population group. This difference was evident in all the regions, but was most marked in Medellín, Valle de Aburrá, Norte and Nordeste, with evidence of a statistical difference in these proportions by region $\left(\mathrm{X}^{2}=41.698 ; p=0.000\right)$.

In terms of area of residence, $94.7 \%$ of elderly persons lived in urban areas and $5.3 \%$ lived in rural areas, which can affect access to health services. This was a statistically significant association $\left(\mathrm{X}^{2}=8455.015 ; p=0.000\right)$. The average age of the elderly individuals was 70.42 years (SD 8.27 years), with 76 the most common age and 50\% of the population group being aged 69 or less. The minimum age was 60 years and the oldest person found in the department was 112 years. The lowest average ages were found in Medellín, Suroeste and Oriente.

In terms of marital status, married people predominated (38.3\%), closely followed by widows (33.4\%); who represented the majority in Medellin, Nordeste, Norte and Valle de Aburrá. It is worth mentioning that in Medellin, Bajo Cauca and Urabá widows and widowers outnumbered married and unmarried elderly persons. Statistical differences were found between the regions in the proportions of marital status $\left(\mathrm{X}^{2}=414.663 ; p=0.000\right)$. 
Health status

According to the results of the Geriatric Depression Scale, $73.7 \%$ of elderly respondents registered no risk of depression; however, the prevalence of risk of $26.3 \%$ was distributed between $16.2 \%$ with a slight risk and $10.1 \%$ with an established risk for depression. By region, the highest prevalence of risk was recorded in the Norte, Suroeste, Occidente and Bajo Cauca, between which there were statistical differences $\left(\mathrm{X}^{2}=232.437 ; p=0.000\right)$ (table 1). Moreover, living in Magdalena Medio, Oriente and Urabá decreased the probability of risk, according to adjusted prevalence ratios for the demographic variables (Table 2).

Table 1. Percentage distribution of elderly persons at risk of depression, anxiety, cognitive impairment, social resources and mistreatment by region. Antioquia, Colombia, 2012.

\begin{tabular}{|c|c|c|c|c|c|c|c|c|c|c|c|c|c|c|c|}
\hline \multirow{2}{*}{ Region } & \multicolumn{3}{|c|}{ Depression $^{1}$} & \multicolumn{2}{|c|}{ Anxiety $^{2}$} & \multicolumn{4}{|c|}{ Cognitive Decline ${ }^{3}$} & \multicolumn{5}{|c|}{ Social Resources ${ }^{4}$} & \multirow{2}{*}{ Abuse } \\
\hline & 1 & 2 & 3 & 1 & 2 & 1 & 2 & 3 & 4 & 1 & 2 & 3 & 4 & 5 & \\
\hline Bajo Cauca & 66.8 & 22.1 & 11.1 & 44.2 & 55.8 & 1.5 & 20.8 & 52.8 & 24.8 & 0 & 13.6 & 46.9 & 34.9 & 4.5 & 10.6 \\
\hline \multicolumn{16}{|l|}{ Magdalena } \\
\hline Medio & 84.9 & 11.9 & 3.2 & 82 & 18 & 0.8 & 33.7 & 56.7 & 8.7 & 0 & 1 & 32.7 & 58.8 & 7.6 & 0 \\
\hline Medellín & 72.5 & 14.6 & 12.9 & 66.6 & 33.4 & 5.1 & 36.4 & 42.7 & 15.8 & 0 & 25.8 & 41.9 & 25 & 7.2 & 8.8 \\
\hline Nordeste & 69.6 & 22.1 & 8.2 & 59.8 & 40.2 & 1.5 & 21.2 & 60.4 & 16.9 & 0 & 23 & 53.6 & 20.2 & 3.2 & 2.1 \\
\hline Norte & 52.8 & 33 & 14.2 & 0 & 100 & 4 & 35.7 & 49.5 & 10.8 & 0.1 & 20.6 & 55.8 & 21.1 & 2.4 & 1.5 \\
\hline Occidente & 60.8 & 30.5 & 8.7 & 0 & 100 & 0.1 & 26.6 & 56.4 & 16.8 & 1.2 & 61.1 & 32.8 & 4.3 & 0.7 & 3 \\
\hline Oriente & 84.2 & 12 & 3.9 & 77.9 & 22.1 & 5.2 & 36.4 & 45.5 & 12.8 & 0.8 & 13.9 & 28.9 & 52.6 & 3.8 & 2 \\
\hline Suroeste & 60.1 & 25.6 & 14.3 & 62.5 & 37.5 & 1.1 & 23.2 & 57.5 & 18.2 & 0.4 & 35.1 & 47 & 17 & 0.5 & 5.4 \\
\hline Urabá & 74.8 & 22.5 & 2.7 & 88.7 & 11.3 & 1.2 & 17.9 & 62.2 & 18.6 & 0 & 31.7 & 55.6 & 11.4 & 1.3 & 6.9 \\
\hline \multicolumn{16}{|l|}{ Valle de } \\
\hline Aburra & 80.7 & 13.5 & 5.8 & 70.1 & 29.9 & 4.4 & 26.4 & 47.9 & 21.2 & 0 & 19.3 & 45.6 & 26.9 & 8.3 & 5.4 \\
\hline
\end{tabular}

${ }^{1}$ Risk of depression $(1=$ normal, $2=$ mild, $3=$ established $) ;{ }^{2}$ Risk of anxiety $(1=$ no risk, $2=$ at risk $) ;{ }^{3}$ Risk of cognitive decline $(1=$ severe, $2=$ moderate, $2=$ mild and $3=$ no risk); ${ }^{4}$ Social resources $(1=\operatorname{good}, 2=$ slightly impaired, $3=$ moderately, $4=$ significantly, $5=$ totally $)$. 
Table 2. Calculation of crude PR adjusted for risk, according to region. Antioquia, Colombia, 2012.

\begin{tabular}{|c|c|c|c|c|c|c|c|}
\hline \multirow{2}{*}{\multicolumn{2}{|c|}{ Variable }} & \multirow{2}{*}{$\begin{array}{l}\text { Raw } \\
\text { PR }\end{array}$} & \multicolumn{2}{|c|}{ CI 95\% } & \multirow{2}{*}{$\begin{array}{c}\text { Adjusted } \\
\text { PR }\end{array}$} & \multicolumn{2}{|c|}{ CI 95\% } \\
\hline & & & Lower & Upper & & Lower & Upper \\
\hline \multirow{10}{*}{$\begin{array}{l}\text { Risk of } \\
\text { depression }\end{array}$} & Bajo Cauca & 2.458 & 1.802 & 3.353 & 1.719 & 1.088 & 2.715 \\
\hline & Magdalena M & 0.470 & 0.320 & 0.691 & 0.242 & 0.142 & 0.414 \\
\hline & Medellín & 1.457 & 1.062 & 1.999 & 1.247 & 0.777 & 2.001 \\
\hline & Nordeste & 1.525 & 1.106 & 2.102 & 1.734 & 1.114 & 2.701 \\
\hline & Norte & 2.511 & 1.831 & 3.444 & 1.090 & 0.633 & 1.876 \\
\hline & Occidente & 1.918 & 1.392 & 2.642 & 1.960 & 1.240 & 3.098 \\
\hline & Oriente & 0.824 & 0.577 & 1.175 & 0.898 & 0.506 & 1.594 \\
\hline & Suroeste & 2.658 & 1.946 & 3.629 & 3.247 & 2.101 & 5.020 \\
\hline & Urabá & 1.635 & 1.185 & 2.254 & 0.675 & 0.422 & 1.082 \\
\hline & Valle de Aburrá & 1.00 & -- & -- & 1.00 & -- & -- \\
\hline \multirow{10}{*}{ Risk of anxiety } & Bajo Cauca & 2.308 & 1.743 & 3.055 & 1.890 & 1.247 & 2.863 \\
\hline & Magdalena M & 0.320 & 0.230 & 0.445 & 0.201 & 0.126 & 0.321 \\
\hline & Medellín & 0.882 & 0.666 & 1.167 & 0.902 & 0.597 & 1.363 \\
\hline & Nordeste & 1.204 & 0.908 & 1.597 & 1.296 & 0.877 & 1.914 \\
\hline & Norte & $\mathrm{NC}$ & $\mathrm{NC}$ & $\mathrm{NC}$ & $\mathrm{NC}$ & $\mathrm{NC}$ & $\mathrm{NC}$ \\
\hline & Occidente & $\mathrm{NC}$ & $\mathrm{NC}$ & $\mathrm{NC}$ & $\mathrm{NC}$ & $\mathrm{NC}$ & $\mathrm{NC}$ \\
\hline & Oriente & 0.485 & 0.351 & 0.670 & 0.585 & 0.355 & 0.963 \\
\hline & Suroeste & 1.045 & 0.786 & 1.389 & 1.263 & 0.856 & 1.862 \\
\hline & Urabá & 0.229 & 0.159 & 0.331 & 0.115 & 0.068 & 0.194 \\
\hline & Valle de Aburrá & 1.00 & -- & -- & 1.00 & -- & -- \\
\hline \multirow{10}{*}{$\begin{array}{l}\text { Risk of } \\
\text { cognitive } \\
\text { decline }\end{array}$} & Bajo Cauca & 0.75 & 0.535 & 1.062 & 0.59 & 0.345 & 1.031 \\
\hline & Magdalena M & 2.44 & 1.593 & 3.737 & 2.00 & 1.071 & 3.735 \\
\hline & Medellín & 1.05 & 0.739 & 1.492 & 1.19 & 0.706 & 2.035 \\
\hline & Nordeste & 1.08 & 0.756 & 1.556 & 1.17 & 0.679 & 2.033 \\
\hline & Norte & 1.38 & 0.940 & 2.037 & 1.20 & 0.580 & 2.501 \\
\hline & Occidente & 0.71 & 0.507 & 1.014 & 0.77 & 0.446 & 1.346 \\
\hline & Oriente & 1.14 & 0.787 & 1.654 & 1.23 & 0.644 & 2.365 \\
\hline & Suroeste & 1.15 & 0.797 & 1.667 & 1.55 & 0.884 & 2.748 \\
\hline & Urabá & 0.99 & 0.692 & 1.419 & 0.72 & 0.407 & 1.292 \\
\hline & Valle de Aburrá & 1.00 & -- & & 1.00 & -- & -- \\
\hline
\end{tabular}




\begin{tabular}{|c|c|c|c|c|c|c|c|}
\hline & \multirow{2}{*}{ Variable } & \multirow{2}{*}{$\begin{array}{c}\text { Raw } \\
\text { PR }\end{array}$} & \multicolumn{2}{|c|}{ CI 95\% } & \multirow{2}{*}{$\begin{array}{l}\text { Adjusted } \\
\text { PR }\end{array}$} & \multicolumn{2}{|c|}{ CI 95\% } \\
\hline & & & Lower & Upper & & Lower & Upper \\
\hline \multirow{10}{*}{$\begin{array}{l}\text { Physical } \\
\text { Dependence }\end{array}$} & Bajo Cauca & 0.555 & .337 & 0.914 & 0.408 & 0.217 & 0.766 \\
\hline & Magdalena M & 0.429 & .252 & 0.729 & 0.630 & 0.345 & 1.151 \\
\hline & Medellín & 2.664 & 1.828 & 3.883 & 3.139 & 1.950 & 5.053 \\
\hline & Nordeste & 1.185 & .776 & 1.810 & 1.047 & 0.593 & 1.847 \\
\hline & Norte & 21.553 & 14.729 & 31.539 & 20.278 & 12.086 & 34.021 \\
\hline & Occidente & 2.360 & 1.595 & 3.493 & 1.918 & 1.107 & 3.321 \\
\hline & Oriente & 1.618 & 1.074 & 2.439 & 1.147 & 0.659 & 1.998 \\
\hline & Suroeste & 1.247 & 0.817 & 1.901 & 1.459 & 0.861 & 2.472 \\
\hline & Urabá & 0.310 & .170 & 0.567 & 0.340 & 0.162 & 0.715 \\
\hline & Valle de Aburrá & 1.00 & -- & -- & 1.00 & -- & -- \\
\hline \multirow{10}{*}{$\begin{array}{l}\text { Nutritional } \\
\text { Risk }\end{array}$} & Bajo Cauca & 3.681 & 2.270 & 5.967 & 3.197 & 1.893 & 5.399 \\
\hline & Magdalena M & 10.583 & 5.220 & 21.456 & 13.072 & 6.393 & 26.731 \\
\hline & Medellín & 0.977 & 0.692 & 1.378 & .892 & 0.617 & 1.291 \\
\hline & Nordeste & 1.321 & 0.912 & 1.913 & 1.287 & 0.868 & 1.908 \\
\hline & Norte & 14.362 & 6.170 & 33.432 & 5.807 & 2.208 & 15.269 \\
\hline & Occidente & 1.994 & 1.315 & 3.022 & .965 & 0.589 & 1.582 \\
\hline & Oriente & 1.018 & 0.709 & 1.461 & 1.108 & 0.758 & 1.619 \\
\hline & Suroeste & 0.986 & 0.692 & 1.406 & .894 & 0.613 & 1.303 \\
\hline & Urabá & 4.536 & 2.683 & 7.668 & 5.191 & 3.024 & 8.911 \\
\hline & Valle de Aburrá & 1.00 & -- & -- & 1.00 & -- & -- \\
\hline
\end{tabular}

$64.2 \%$ of older adults at risk of depression were women and $35.8 \%$ were men. For every woman at risk of depression there were 0.9 men, or in other words, the risk of depression for men was $10 \%$ lower $(\mathrm{PR}=0.91$ [0.820; 1.004]); however, no statistically significant association was found between gender and risk of depression $\left(X^{2}=3.58 ; p=0.58\right)$.

Elderly widows or widowers had a risk of depression of $36.4 \%$, compared to $30.8 \%$ for married elderly individuals and $17.6 \%$ for elderly unmarried persons. A statistically significant association between marital status and the risk of depression was found $\left(\mathrm{X}^{2}=60.23 ; p=0.000\right)$.

For every elderly individual at risk of depression residing in rural areas there were 0.9 elderly persons at risk of depression residing in urban areas. The fact of living in urban areas could therefore be considered as a protective factor in reducing the risk of depression ( $\mathrm{PR}=0.903$ [0.764; 1.068]); no statistically significant association was found between area of residence and risk of depression $\left(\mathrm{X}^{2}=1.37 ; p=0.241\right)$. 
According to the scale of anxiety, 34.4\% of older adults were at risk of anxiety. By region, the prevalence of risk of anxiety was higher in the Norte and Occidente where all the elderly individuals were at risk for this mental disorder, followed by Bajo Cauca where a little more than half presented the same risk. This association is statistically significant $\left(\mathrm{X}^{2}=1464.828 ; \mathrm{P}=0.000\right)$ (Table 1). Living in Bajo Cauca, the Northeast and Suroeste increased the likelihood of developing the disorder, while living in other regions acted as a protective factor, except the Norte and Occidente (Table 2).

Of the elderly persons in the department, $67.7 \%$ were female, among whom the prevalence of risk was $48.3 \%$, compared with a prevalence among men of $37.5 \%$. For every woman at risk of anxiety there were 0.77 men with the same risk, or in other words, being a man reduced the risk by $33 \%$ $(\mathrm{PR}=0.77[0.720,0.837])$. There was a statistically significant association between gender and risk of anxiety $\left(\mathrm{X}^{2}=46.0 ; p=0.000\right)$.

Of the elderly individuals at risk of anxiety $37.3 \%$ were married, $32.3 \%$ were widowed and $16.3 \%$ were single. The lowest percentages were among divorced individuals and those living in a civil union. There was a statistically significant association between marital status and risk of anxiety $\left(\mathrm{X}^{2}=13.46 ; p=0.019\right)$.

$90.7 \%$ of older adults at risk of anxiety lived in urban areas and 9.3\% lived in rural areas. For every adult at risk of anxiety that lived in an urban area there were 0.86 elderly persons living in rural areas, in other words, living in rural areas could be considered as a protective factor against the risk of an anxiety disorder ( $\mathrm{PR}=0.865$ [0.772, 0.968]); a statistically significant association between area of residence and the risk of anxiety was found $\left(\mathrm{X}^{2}=5.75 ; p=0.016\right)$.

The MMSE scale used to determine the risk of cognitive impairment, found that $83.2 \%$ of elderly individuals had some degree of impairment, mainly mild $(46.9 \%)$. Residents in the regions of
Magdalena Medio, Norte and Oriente were more at risk, while Bajo Cauca, Valle de Aburrá, Urabá and Suroeste were lower risk regions; This difference was statistically significant $\left(\mathrm{X}^{2}=283.568 ; p=0.000\right)$ (Table 1), but living in regions such as Bajo Cauca, Occidente and Urabá represented a protective factor, once adjusted for demographic variable conditions (Table 2).

A total of $61.9 \%$ of the older adults with a risk of cognitive impairment were women, and for every woman at risk there were 0.99 men $(\mathrm{PR}=0.99$ $[0.868,1.146])$. However, there was no statistically significant association between gender and the risk of cognitive impairment $\left(\mathrm{X}^{2}=0.001 ; \mathrm{p}=0.971\right)$.

Of the older adults at risk of cognitive impairment, over $50 \%$ were single, separated, widowed or divorced, and the remainder were married or lived with a partner. There was a statistically significant association between marital status and risk of cognitive impairment ( $p=0.000$ $\mathrm{X}^{2}=38.70$ ). A total of $91.9 \%$ of the elderly persons at risk of cognitive impairment lived in urban areas, with each individual representing 0.96 of an individual residing in rural areas $(\mathrm{PR}=0.96[0.758$, 1.237]). No statistically significant association was found between the area of residence and the risk of cognitive impairment $\left(X^{2}=0.065 ; p=0.798\right)$.

A total of $81.7 \%$ of the elderly persons described themselves as independent or not needing help according to the Katz index, which measures the ability to perform basic daily activities such as bathing, dressing, using the toilet, moving around, bladder and bowel control and feeding oneself. In other words, the prevalence of physical disability or reduced functional capacity is $18.3 \%$. The lowest functional capacity was found in the Norte region $(72.9 \%)$ and in the city of Medellin (24.1\%) while the highest independence was found in the Bajo Cauca and Urabá regions. There were statistically significant differences between the regions $\left(\mathrm{X}^{2}=1343.621 ; \mathrm{p}=0.000\right)$ (Table 1$)$. Similarly, living in these regions represented a protective factor (Table 2). 
It was found that $35.6 \%$ of older people in the department had moderately impaired social resources and $22.2 \%$ considerably impaired social resources, according to the OARS scale. There were statistical differences between the regions. The elderly persons of Bajo Cauca, Medellin, Nordeste, Norte, Suroeste, Urabá and Valle de Aburrá presented moderately impaired social resources; those in the regions of Magdalena Medio and Oriente had considerably impaired social resources; and those in the Occidente had slightly impaired social resources $\left(\mathrm{X}^{2}=902.473\right.$; $p=0.000)$ (table 1).

The nutritional status of the elderly was measured by the Determine scale. The prevalence of nutritional risk among the elderly was $83.4 \%$, with $59.9 \%$ at high risk and $23.6 \%$ at moderate risk. It is a concern that only $16.6 \%$ of the elderly persons had good nutritional status, mainly in the regions of Oriente (21.6\%) and Medellin, Suroeste, Valle de Aburrá and Nordeste, with percentages above $15 \%$, a statistically significant association $\left(\mathrm{X}^{2}=22002.934 ; p=0.000\right)$. The regions which represented an increased probability of this risk were Magdalena Medio, Norte and Urabá (Table 2).

It is worthy of note that $7.6 \%$ of older people in the department have experienced some form of abuse, primarily psychological, such as neglect, failing to assist or preventing the elderly individual from keeping in touch with family and friends, or by insulting, shouting, intimidating, or threatening the elderly person. The highest prevalences were registered in Urabá (6.7\%) and Medellin (6.3\%). Neglect, considered a lack of food, shelter, hygiene or medical care offered by the family of the elderly person, was more prevalent in the Valle de Aburrá (5.5\%), Bajo Cauca (3.3\%) and Medellín $(2.5 \%)$. Economic abuse was higher, in terms of percentage, in the regions of Valle de Aburrá and Medellin, at $1.7 \%$, and Bajo Cauca, at 1.5\%. It should be noted that in the Magdalena Medio region no type of abuse was recorded against elderly individuals while three regions had all kinds of abuse, Valle de Aburrá, Medellin and
Bajo Cauca. These differences were statistically significant $\left(\mathrm{X}^{2}=106.306 ; p=0.000\right)$ (table 1$)$.

\section{DISCUSSION}

In 43 years the population of Colombia has practically doubled, based on figures of $21,344,816$ inhabitants in 1970 and 46,581,823 in 2012, of which, according to DANE, $10.2 \%(4,792,957)$ are aged 60 years and over. The departments of Antioquia, Valle del Cauca, Cundinamarca, Santander, Atlántico, Bolívar and Tolima are home to the majority of people aged 60 and over, while the highest percentages of such individuals are found in the departments of Bogotá, Medellín, Cali and Barranquilla.

Colombia has participated in the issue of aging at an international level in a number of contexts such as the 1994 Cairo International Conference on Population and Development and the $2000^{4}$ Madrid International Plan of Action on Ageing, and nationally through the Política Nacional de Envejecimiento y Vejez (2007-2019) (the National Policy on Ageing and Old Age). ${ }^{2}$ This reveals the need to reflect on issues relating to how the elderly live today, with the aim of advancing, through the contribution of scientific evidence that facilitates the estimation of future needs, public policy that meets the requirements of this population.

In this sense, the present study is consistent with national and international guidelines, since it allows a diagnosis of the main risks to the health of the elderly, where the experiences of the past facilitate good current health, resulting in a greater emphasis on mental health, as everyone experiences tension and stress at some point in life, a situation that causes a reduction in the control of feelings, ideas and behaviors that impair mood and can result in physical and mental illness and limited functionality.

In Colombia, the prevalence of depression among those older than 65 years is $16.5 \%$ in the 
community and $29 \%$ among those in primary care. Less than half of these cases are recognized, due to insufficient awareness of the impact of the disease among this population and the fact that there are no clear risk factors and early signs of the disease. ${ }^{10,11}$

Internationally, the World Health Organization believes that depression will be the second leading cause of disability, after heart disease, by 2020 . It is becoming a serious disease that affects not only mood, but can also lead to functional and cognitive impairment. Among the elderly, depression mainly affects people with chronic conditions and can cause suffering, disability and family breakdown, worsening the results of many diseases and increasing mortality. ${ }^{10-12}$

According to the results found in Antioquia when the Yesavage Geriatric Depression Scale was applied, a prevalence of risk of $26.3 \%$ was identified, a result well above figures reported in 2012 by the Encuesta Nacional de Demografía y Salud de Colombia (2010) (the Colombia National Survey of Demographics and Health), in which an overall prevalence of depression of $9.5 \%$ was reported, which was higher among women $(\mathrm{PR}=1.74)$, the disabled ( $\mathrm{PR}=14.21)$ and those with comorbidities such as brain disease $(\mathrm{PR}=2.09)$, heart disease $(\mathrm{PR}=1.49)$, diabetes $(\mathrm{PR}=1.19)$ and Alzheimer's Disease $(\mathrm{PR}=2.13)$ and was lower among those with higher levels of education $(\mathrm{PR}=0.14) .{ }^{13}$

The prevalences of risk of depression in the present study were below those reported in Cuba, where $27.1 \%$ of elderly residents had symptoms of mild depression; $16.6 \%$ had moderate depression and $14.7 \%$ had severe depression, ${ }^{14}$ and also below those reported in a study in the metropolitan region of the city of Guadalajara - Jalisco, Mexico, featuring 246 older adults, in which a prevalence of depression of $36.2 \%$ of subjects studied, $43.2 \%$ among women and $27.1 \%$ among men, was observed. This prevalence was also associated with factors such as being unemployed $(\mathrm{PR}=4.21)$, widowed $(\mathrm{PR}=3.16)$ or single $(\mathrm{PR}=2.32)$, or being older than 80 years $(\mathrm{PR}=2.90) \cdot{ }^{15} \mathrm{~A}$ study of institutionalized elderly persons in Brazil found a prevalence of depression of $50 \%$, which was severe in $13.7 \%$ of cases, and was significantly associated with age, gender, ethnicity, and physical activity. ${ }^{16}$

Among the regions of the department of Antioquia surveyed by the present study, Norte, Suroeste, Occidente and Bajo Cauca had the highest prevalence of depression. It is worth noting that violence does not affect these regions as much as it does sub-regions such as Urabá, Oriente and Magdalena Medio, suggesting a potential confluence with another group of factors which may indicate an explanation for the health status of elderly adults living in care homes.

It can be concluded that depression is a common condition among the elderly, which brings suffering and impaired quality of life and can be a risk factor for other diseases or even death. Despite the high prevalence of the disorder, it is usually under-diagnosed and under-treated, and so early detection and early treatment is essential. ${ }^{17}$

The prevalence of mental illness increases with age, as there are people who begin to develop mental illness in their youth and people who develop the condition as older adults, where factors such as social isolation, reduced autonomy, economic hardship, declining health, and proximity to death are associated with aging, leading to an increase in anxiety disorders among older adults. These conditions are generally atypical, and are often underdiagnosed. ${ }^{18}$

According to the anxiety scale applied, 34.4\% of elderly persons in the department were at risk of anxiety, a finding that coincides with results reported in Xalapa, Mexico, where 48\% of elderly people were at risk. ${ }^{19}$ In a Mexican study of generalized anxiety among the elderly, it was found that the estimated prevalence of anxiety disorders among the elderly ranged from 3.2\% to $14.2 \% .^{20}$

Generally, biological factors are more important for predicting depression than anxiety, which is why 
there are so few studies related solely to the former, and associated risk factors; there is a differential effect of social factors on depression. This is the main association it has with anxiety, which is one of its symptoms. There is a considerable overlap between risk profiles for anxiety and depression among the elderly, recommending a dimensional approach to studying the relationship between anxiety and depression, in order to increase awareness and improve preventive mental health programs, so generating a clearer understanding and differentiating between the etiological factors of each condition. ${ }^{21,22}$

The present study found that $83.2 \%$ of elderly persons have some risk of cognitive decline, a much higher percentage than findings in Cuba for adults over 65 years, which were $3.7 \%$, and for dementia, which were $8.2 \% .{ }^{23}$ Another study of dementia in 281 patients over 60 years found an estimated prevalence of $17.4 \% .{ }^{24}$ Based on the evidence presented, it can be argued that cognitive decline in the elderly is not uncommon, which when added to the aging process represents a death risk, which, according to some authors, doubles every eight years, as age advances, demonstrating the importance of early diagnosis and greater medical knowledge, ${ }^{25,26}$ especially as in countries such as Colombia and Brazil there is evidence that the treatment of this decline by professionals has positive effects on the elderly in question.

In Colombia a study of the cognitive effects of combined memory and psychomotor training in older adults, ${ }^{27}$ found positive effects following combined SIMA memory and psychomotor training, specifically in terms of the selective attention and SIP of healthy older adults. Also, a study of healthy older adults found that cognitive therapy can lead to improved performance of memory tasks and simple calculations. ${ }^{28}$

In terms of functional disability found in this study, only $18.3 \%$ of elderly persons had such disability, with a higher prevalence among women, similar to findings in Argentina, ${ }^{26}$ and Mexico, ${ }^{29}$ with lower dependency among the elderly for the performance of basic activities. It is necessary to consider the factors that may trigger or generate functional disability, such as falls, and in this sense the evidence from the region of Oeste de Santa María, Brazil where factors that predisposed older adults to falls and the incidence of falls was $75 \%$ for the 20 adults in the study, who had a mean age of 75 years. The incidence of falls was associated with cognitive impairment, visual disturbances and home environment. ${ }^{30}$

Functional capacity is an important part of the health status of the elderly, as has been described by Soberanes et al., ${ }^{31}$ affecting energy levels, pain, sleep, social isolation and mobility. The same results were found when men and women were analyzed. With regard to age, it is important to note that there are significant differences between the functional capacities of people over 80 , in terms of factors such as energy and mobility; and those over 70 , in terms of pain and mobility; similar results were found for elderly persons in Antioquia. In this sense it is important to emphasize the promotion of healthy lifestyles and performing of physical activity, as has been done in Brazil. ${ }^{32}$

Social networks play an important role in the quality of life of older adults. Some studies have shown that social networks diminish and narrow in old age, and that older people seeking to reconfigure their social networks turn not to the family for their primary emotional support and connections, but seek integration with other generational peers such as their friends and neighbors, ${ }^{33}$ a process directly or indirectly affected by spirituality. A literature review performed in Brazil ${ }^{34}$ found that aging is closely related to spirituality/religiosity, yet few studies have considered this situation.

The present study found that all the elderly persons $(99.9 \%)$ had impaired social resources, a situation that may reveal a failing in the moral support that the elderly need at this stage of life. This deficiency does not occur only because of age, but also due to the absence of family, resulting from spatial displacement, which forces families to separate for economic, labor and social conflict 
reasons. While everyone needs a social fabric that supports them throughout their daily life, the absence of this fabric is most evident at the beginning and end of life (among children and the elderly) when it can generate a greater burden on the decline of the conditions of life and health of people.

A study carried out of the social networks of the population aged over 60 years living in situations of urban poverty in the department of Quindío, found that more than half (52.62\%) of poor elderly persons felt that they did not have a single bond or connection with a friend or neighbor. ${ }^{35}$

With regard to abuse and other violence suffered by the elderly, this is a complex problem that has assumed growing global relevance in recent years. Abuse, not only globally but also in Colombia, is steadily rising, becoming a public health problem in a number of countries, regardless of their level of development. ${ }^{36}$ Until recently, however violence against older adults by family members has been virtually ignored, an unacceptable situation, given that the elderly, as well as being weak, dependent, or disabled are the subject of mistreatment within their own family, mainly at the hands of their children. ${ }^{37}$

The situation in Brazil is little different, as reflected in a study of abuse by domestic violence among adults in the Distrito Federal (Federal District), ${ }^{38}$ where an increase in complaints of abuse since 2003 was found. These were more evident for men, but while in $62.81 \%$ of cases the alleged perpetrator was not related to the victim, $13.56 \%$ of individuals were abused by their own children. However, a dearth of up to date epidemiological data showing the true statistical dimension of the problem across the various forms of abuse that older adults endure emphasizes the need for further detailed studies. ${ }^{39}$

However, abuse in the family environment involving family members or caregivers is difficult to identify because of the inability of the elderly individual to recognize the abuse he or she is suffering due to the fear of being severely punished, or because the abuse is clandestine, avoiding any visible signs of trauma. ${ }^{40,41}$

The most frequently reported type of abuse in the department of Antioquia was psychological, similar to findings in Washington ${ }^{42}$ and Cuba. ${ }^{42}$ Being ignored by a person the elderly individual lives with, or the elderly person feeling their emotional needs were neglected, or that they were prevented from having contact with family and friends, or shouted at, insulted, intimidated or threatened are characteristics of this type of abuse. Emotional abuse can exist without physical violence, having serious consequences from the point of view of emotional well-being. Many psychiatrists diagnose psychotic profiles in people who are actually suffering the consequences of chronic psychological abuse, and those subjected to chronic situations of violence in the home undergo a gradual weakening of their physical and psychological defenses, which translates into an increase in health problems, mainly psychosomatic diseases and depression. ${ }^{42}$

Finally, another factor taken into account by the present study is with nutritional status, which if healthy, significantly promotes a suitable functional and mental status, thereby helping to improve the quality of life of individuals. Nutritional status, as a concentrated expression of health status, can determine the ability of the elderly individual to adapt to the changes that age brings; while preserving a nutritional state can generate increased degrees of autonomy and thus a better family, work and social performance and the feeling of the fullness of life. ${ }^{43}$ Oral health and its relationship with nutrition has also been studied, as described by Ribeiro et al., ${ }^{44}$ who presented a literature review of the major diseases of the oral cavity of the elderly and their relationship and importance to nutrition.

A prevalence of nutritional risk of $79.0 \%$ of older adults was found in the department of Antioquia. Similar findings were found in Mexico 
where $73 \%$ were at overall risk ${ }^{45}$ and in Venezuela where there was a $48.4 \%$ risk of malnutrition ${ }^{46}$ among the elderly.

An important strength of this study was that it was of sufficient size to generate population-based results, although its cross-sectional descriptive design prevents causal relationships being studied, representing a limitation of the study design. The study was also limited in its use of instruments that measured only signs and symptoms that indicate the presence or risk of a disorder, but not a disease, and so studies using this type of design and the same tools were favored in the discussion, where possible. Additionally, exploring the prevalence of abuse in the presence of family members or persons responsible for the elderly individual may have led to the undervaluing of a problem that may be more complex than the evidence presented here, as it is precisely the family members or persons close to the elderly, who are directly involved in the different types of abuse referenced in this study and literature in general.

\section{CONCLUSIONS}

Women predominated among the elderly population of the department of Antioquia, most likely due to their survival rate. The large proportion of elderly persons, especially women, in a state of widowhood was evident. This is possibly due to factors that favor this situation, such as longer life expectancy, leading to a culture of the "feminization of aging" and the recommendation of studies differentiated by gender to anticipate this demographic change that people undergo as a result of the aging process.

The mental health of the elderly is seriously compromised, with a prevalence of risk of depression of $26.3 \%$, a risk of anxiety of $34.4 \%$ and a risk of cognitive decline of $83.2 \%$, higher than other studies in Latin America, which shows how mental impairment, which can largely be derived from age, but also through suffering adverse situations, affects health, and indicating the need for an individualized study of the pathologies in question, in order to determine the causal factors of risk associated with the presence of these conditions and avoid a deterioration in the quality of life, health conditions and functional and emotional dependence on the family and the state.

It was found that about one in ten elderly persons had suffered some type of abuse, primarily psychological, but also physical, economic and sexual. This indicates a deterioration in family relationships and a loss of social fabric surrounding the elderly, and shows the importance of such individuals being able to identify the violence perpetrated against them, and also that this situation is also highly socially invisible when a loved one is the aggressor. It is therefore recommended that studies on this subject are expanded so that the authorities can exercise control and avoid the problem as much as possible.

In terms of nutritional status, it is regrettable that the prevalence of malnutrition risk is so high and greater than that recorded among elderly individuals from other countries, showing how economic uncertainty adds another element to vulnerability, and is also a risk factor that compromises health, functional capacity and quality of life.

The risks were not distributed equally between the different regions, indicating social and health inequities, determining a situation of difference for elderly persons in the department, who require public policies for each region, according to the expressed needs of each.

It is recommended that these descriptive studies are expanded with a greater population inference, through the use of expansion factors, describing the current picture of the elderly of the department, but also including structural determinants. At point level, analytical studies to determine risk factors, risk behaviors and vulnerability conditions are recommended, which can support public policies aimed at health promotion and prevention and also harm reduction. 


\section{REFERENCES}

1. Organización Panamericana de la Salud. Resúmenes metodológicos en epidemiología: análisis de la situación de salud ASIS. Bol Epidemiol 1999; 20(3):1-3.

2. Colombia. Ley 1251, por la cual se dictan normas tendientes a procurar la protección, promoción y defensa de los derechos de los adultos mayores. Bogotá: Congreso de la República; 2008.

3. Naciones Unidas. Informe de la Segunda Asamblea Mundial sobre el Envejecimiento. Madrid: Nações Unidas; 2002.

4. Cardona D, Estrada A, Agudelo H. Envejecer nos Toca a todos. Medellín: Universidad de Antioquia, Facultad Nacional de Salud Pública; 2003.

5. Ham-Chande R. Esperanzas de vida y expectativas de salud en las edades avanzadas. Demográf Urb 2001;16(3):545-60.

6. Comissão Econômica para Améria Latina e o Caribe. Estrategia regional de implementación para América Latina y el Caribe del Plan de Acción Internacional de Madrid sobre el Envejecimiento. Santiago de Chile: NU/CEPAL; 2003.

7. Barros C. Aspectos sociales del envejecimiento. En: Anzola Perez E, Galinsky D, Morales Martinez F, Salas A, Sánchez Ayéndez M, editores. La atención de los ancianos: un desafío para los años noventa. Whashington: Organização Panamericana de la Salud; 1994. (Publicación Científica, 546). p. 57-66.

8. Folstein MF, Folstein S, McHugh PR. Mini-mental state. A practical method for grading the cognitive state of patients for the clinician. J Psychiatr Res 1975;12(3):189-98.

9. Centro Latinoamericano y Caribeño de Demografía. Manual sobre indicadores de calidad de vida en la vejez. Santiago de Chile: CELADE/CEPAL; 2006.

10. Steffens DC. A multiplicity of approaches to characterize geriatric depression and its outcomes. Curr Opin Psychiatr 2009;22(6):522-6.

11. Nelson CJ, Cho C, Berk AR, Holland J, Roth AJ. Are Gold standard depression measures appropriate for use in geriatric cancer patients?: a systematic evaluation of self-report depression instruments used with geriatric, cancer, and geriatric cancer samples. J Clin Orthod 2010;28(2):348-56.
12. Alexopoulos GS. Depression in the elderly. Lancet 2005;365(9475):1961-70.

13. Aldana OR, Pedraza MJ. Análisis de la depresión en el adulto mayor en la encuesta nacional de demografía y salud 2010 [Internet]. Bogotá, DC:Universidad del Rosario; 2012 [acesso em 01 jun. 2015]. Disponível em: http://repository.urosario.edu.co/bitstream/ handle/10336/3002/932060822012.pdf;jessionid=E8 5365330664E78042261D630B3B2BED? sequence $=3$

14. González M. Depresión en ancianos: un problema de todos. Rev Cuba Med Gen Integr 2001;17(4):316-20.

15. Pando Moreno M, Aranda Beltrán C, Alfaro Alfaro N, Mendoza Roaf P. Prevalencia de depresión en adultos mayores en población urbana. Guadalajara - Jalisco, México 2001. Rev Esp Geriatr Gerontol 2001;36(3):140-4.

16. Gonçalves VC, Andrade KL. Prevalência de depressão em idosos atendidos em ambulatório de geriatria da região nordeste do Brasil (São Luís-MA). Rev Bras Geriatr Gerontol 2010;13(2):289-99.

17. Peña-Solano DM, Herazo-Dilson MI, CalvoGómez JM. Depresión en Ancianos. Rev Fac Med 2009;57(4):347-55.

18. Boggio MJ. Ansiedad en el adulto mayor: revisión bibliográfica. Rev Electr PortalesMedicos.com [Internet] 2011; [acesso em 12 fev. 2013];4 telas. Disponível em: http://www.portalesmedicos.com/ publicaciones/articles/3649/1/Ansiedad-en-el-adultomayor-Revision-bibliografica.html

19. Quiroz COA, Flores RG. Ansiedad y depresión en adultos mayores. Psicol Salud 2007;(2):291-300.

20. Instituto de Seguridad y Servicios Sociales de los Trabajadores del Estado [Internet]. México: ISSSTE; 2013. Trastorno de ansiedad generalizada; 2013 [citado em 12 de feb 2013]. Aproximadamente 2 telas]. Disponível em: http://sgm.issste.gob. $\mathrm{mx} / \mathrm{medica} / \mathrm{medica}$ documentacion/guias_ autorizadas/Psiquiatr\%C3\%ADa/IMSS-499-11Ansiedad\%20generalizada/IMSS-499-11-GER_ AnsiedadGeneralizada.pdf

21. Vink D, Aartsen MJ, Schoevers RA. Risk factors for anxiety and depression in the elderly: a review. J Affect Disord 2008;106(1-2):29-44. 
22. Lenze EJ, Mulsant BH, Shear MK, Alexopoulos GS, Frank E, Reynolds CF 3rd. Comorbidity of depression and anxiety disorders in later life. Depress Anxiety 2001;14(2):86-93.

23. Sánchez YY, López AM, Calvo M, Noriega L, López J. Depresión y deterioro cognitivo. Estudio basado en la población mayor de 65 años. Rev Habanera Cienc Méd [Internet] 2009 [acesso em 12 fev 2013];8(4):19. Disponível em: http://scielo.sld.cu/scielo. php?script=sci_arttext\&pid=S1729519X2009000400 $008 \& \operatorname{lng}=$ es.

24. Pérez Martínez V. Prevalencia del síndrome demencial en la población mayor de 60 años. Rev Cubana Med Gen Integr 2004;20(4):1-7.

25. Costa JM. Trastornos cognitivos en psicopatología. Barcelona: JR Prous; 1995.

26. Serrani D. Modelo psicosocial y de género de la discapacidad funcional en Adultos Mayores. El rol del afrontamiento proactivo y los recursos sociales. Alcmeón 2008;14(4):42-55.

27. Valencia C, López-Alzate E, Tirado V, Zea-Herrera MD, Lopera F, Rupprecht R, et al. Efectos cognitivos de un entrenamiento combinado de memoria y psicomotricidad en adultos mayores. Rev Neurol 2008;46(8):465-71.

28. Da Silva TBL, Valente AC, Vianna DL, Malagutti MP, Pereira VM, Sanches M. Treino cognitivo para idosos baseado em estratégias de categorização e cálculos semelhantes a tarefas do cotidiano. Rev Bras Geriatr Gerontol 2011;14(1):65-74.

29. Pérez Reyes MS, Santiago García CE. Capacidad funcional del adulto mayor de una institución de primer nivel de atención. México: Universidad Veracruzana, unidad docente multidisciplinaria de ciencias de la salud y trabajo social; 2010.

30. Piovesan AC, Foletto HM, Medianeira J. Fatores que predispõem a quedas em idosos residentes na região oeste de Santa Maria, RS. Rev Bras Geriatr Gerontol 2011;14(1):75-83.

31. Soberanes F, González P, Moreno C. Funcionalidad en adultos mayores y su calidad de vida. Rev Esp Med Quir 2009;14(4):161-72.

32. Saranz A. Exercício físico e o processo saúde-doença no envelhecimento. Rev Bras Geriatr Gerontol 2010;13(1):153-8.
33. Sánchez C. Compromiso social de la gerontología con el envejecimiento de las persona. In: Gerontología y desarrollo humano en el siglo XXI: persona adulta mayor, experiencia y desarrollo sostenible. $3^{\circ}$ Congreso Internacional de Gerontología. $5^{a}$ Conferencia Internacional de AIUTA; 15-17 nov 2010; San José. San José: Universidad de Costa Rica; 2010

34. Lucchetti G, Granerp AL, Modena R, Nasri F, Salete Aparecida A. O idoso e sua espiritualidade: impacto sobre diferentes aspectos do envelhecimento. Rev Bras Geriatr Gerontol 2011;14(1):159-67.

35. Quintana U, Gómez S. Estructura de las redes sociales de la población mayor de 60 años en contextos urbanos de pobreza, del departamento del Quindío. Rev Invest Univ Quindío 2010;(21):120-9.

36. Sepúlveda-Carrillo GJ, Arias-Portela JY, CuervoRojas AM, Gutiérrez ST, Olivos-Álvarez SA, Rincón-Hernández MA, et al. Caracterización de los casos de maltrato en el adulto mayor denunciados en la Comisaría Primaria de Familia en la localidad de Usaquén en el año 2007. Rev Colomb Enferm 2009;4(1):39-45.

37. Aguilera Escalona JR, Ramírez Rodríguez R, Aguilhera Pérez R. La violencia psicológica al anciano en la familia. Psicol Am Lat 2009;(18):1-6.

38. Cunha ML, Gonçalves AC, Pereira C, Buriti L. Características dos idosos vítimas de violência doméstica no Distrito Federal. Rev Bras Geriatr Gerontol 2012;15(3):555-66.

39. De Sousa DJ, White J, Soares LM, Teixeira NG, Teixeira NF, D’Elboux MJ. Maus-tratos contra idosos: atualização dos estudos brasileiros. Rev Bras Geriatr Gerontol 2010;13(2):321-28.

40. Tabueña CM. Los malos tratos y vejez: un enfoque psicosocial. Interv Psicosoc 2006;15(3):275-92.

41. Santaló Docampo L, Lacaba Barreto R, Serrano Santana C. Comportamiento de la violencia intrafamiliar en el adulto mayor. Revista Arch Méd Camagüey 2009;13(6):1-5.

42. Querol Martínez C, Pérez Martínez VT, Cardona Y, Inclán L. Maltrato en los ancianos: un reto a la atención primaria de salud geriátrica. Rev Cuba Med Gen Integ 2005;21(1-2):1-5. 
43. Angarita C, Contreras C. Una adecuada nutrición, el pilar de la calidad de vida en el adulto mayor. Cent Colomb Nutr integral;(8):12.

44. Ribeiro AF, Campos LMC, Marques APO. Importance of geriatric dentistry to elderly nutrition / Importância da Odontogeriatria no aspecto nutricional do idoso. Rev Gaúch Odontol 2012;60(2):241-46.

Received: October 17, 2014

Revised: July 27, 2015

Approved: September 03, 2015
45. Gutiérrez T, Silva M, Peñarrieta M, Gonzalez G, Florez F, Gonzalez N. Riesgo nutricional en adultos de mayores de 60 años. Desarro Cient Enferm 2009;17(2):62-6.

46. Rodríguez N, Hernández R, Herrera $\mathrm{H}$, Barbosa J. Estado nutricional de adultos mayores institucionalizados venezolanos. Invest Clín 2005;46(3):219-28. 